\title{
Negative pressure wound therapy: the past and the future
}

\author{
Negatieve druktherapie: het verleden en de toekomst
}

\author{
M.L. Go, M. Or, B. Van Goethem, A. Kitshoff, E. Abma, H. de Rooster \\ Small Animal Department, Faculty of Veterinary Medicine, \\ Ghent University, Salisburylaan 133, B-9820 Merelbeke, Belgium \\ mei.go@ugent.be
}

\begin{abstract}
$\mathrm{A}_{\text {sismacr }}$
Negative pressure wound therapy (NPWT) involves the application of negative pressure on a wound bed for its positive effects on wound healing. Indications for NPWT concern various types of wounds, skin grafts and flaps, partial-thickness burns, open abdomen management and closed incisions.

Negative pressure wound therapy has been used for centuries in human medicine. Its first use dates back to the Roman era (around 27 BCE) when human generated pressures were used. Later, European and Russian physicians developed various advanced methods and systems to apply negative pressure on wounds or other injuries. The on-going positive findings in human medicine triggered researchers in veterinary medicine to apply this technique on animal patients.

However, much still has to be investigated regarding NPWT, especially in veterinary medicine, as there are many factors playing a role in the mechanisms of this treatment. New methods and techniques are continuously being developed and the existing studies show great potential for NPWT.
\end{abstract}

\section{SAMENVATTING}

Bij negatieve druktherapie wordt het wondbed onderworpen aan een negatieve druk omdat dit positieve effecten heeft op de wondheling. Negatieve druktherapie kan worden toegepast op verschillende soorten wonden, huidtransplantaten en -flappen, open abdomen en gesloten incisies.

Negatieve druktherapie wordt al eeuwen gebruikt in de humane geneeskunde. Al in de Romeinse tijd (rond 27 v.Chr.) gebruikte men door mensen gegenereerde zuigkracht om verwondingen beter te laten helen. Europese en Russische artsen ontwikkelden later verschillende geavanceerde methoden en systemen om negatieve druk op wonden toe te passen. De positieve bevindingen in de humane geneeskunde wakkerden de interesse van onderzoekers in de diergeneeskunde aan. De laatste twintig jaar wordt negatieve druktherapie bij dieren ingezet in talrijke experimentele en klinische omstandigheden, maar veel onderzoek moet echter nog gedaan worden.

Anderzijds worden voortdurend nieuwe technieken ontwikkeld en de bestaande studies voorspellen veelbelovende toekomstmogelijkheden voor negatieve druktherapie in de diergeneeskunde.

\section{INTRODUCTION}

Wound healing can be divided into different phases (Buchanan et al., 2014; Balsa and Culp, 2015). The first phase is the inflammatory phase, which comprises a vascular response for hemostasis and a cellular response with leukocyte infiltration. Subsequently, the proliferation phase starts, defined by fibroplasia, angiogenesis and epithelization. The initial part of this phase is hallmarked by the formation of fibroblasts, collagen and new blood vessels, presenting clinically as granulation tissue. After the cellular proliferation, wound contraction is initiated and in combination with reepithelialization, the wound bed becomes smaller. In the last phase, the formation of scar tissue occurs, which is called remodelling. This final phase of wound healing may last for months or even years.

From a surgical point of view, there are different approaches to wound closure. With primary or delayed primary closure, the joining of wound edges before granulation tissue formation is attempted and it is applicable to acute, non-contaminated or minimally contaminated wounds. It results in 'per primam' healing. When wounds cannot be closed with primary closure because of the large size or degree of contamination, they can be allowed to close by second intention healing. Wound healing will pass all phases and is called 'per secundam' healing. Surgically closing a wound after the formation of granulation tissue is called 'per tertiam' healing, and indications involve chronic, contaminated and infected wounds (KnappHoch and de Matos, 2014; Balsa and Culp, 2015). In wounds that do not allow primary closure, various wound treatments can be exploited to optimize wound healing and shorten the time before definitive wound closure may be considered. One of these approaches 


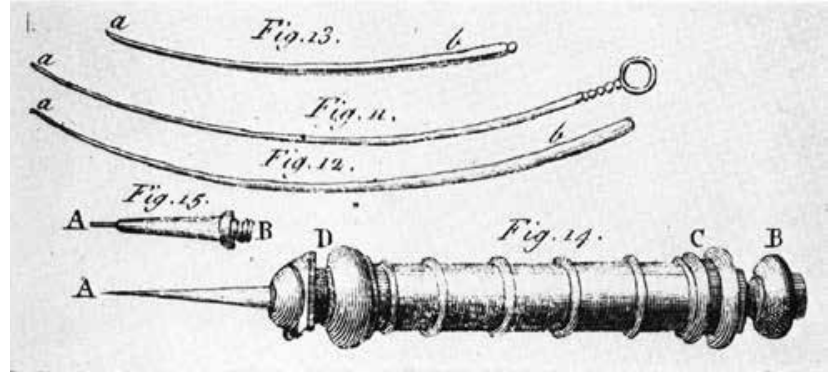

Figure 1. Drawing of an Anel syringe (Price, 1969).

is negative pressure wound therapy (NPWT). Negative pressure has been used for centuries in the treatment of various wounds and diseases in human patients (Miller, 2012). Already during the Roman era (around $27 \mathrm{BCE}$ ), negative pressure was applied on wounds in the form of human-generated pressures (Price, 1969; Miller, 2012). With time, instruments and devices were invented to generate more suction and to control the pressure applied to the patient in a better way (Howe, 2015).

Over the last twenty years, NPWT has been further developed in both human and veterinary medicine. Although animals were mostly used as study models for human medicine, the advantages indicated by the literature in human medicine have recently attracted the attention of researchers in the veterinary field (Howe, 2015).

In recent years, NPWT has already been the topic of other articles published in Vlaams Diergeneeskundig Tijdschrift; besides a review article on the mechanics of NPWT (Spillebeen et al., 2013), three case reports are available (Jordana-Garcia et al., 2011; Abma et al., 2015; Lippens et al., 2016). The current article provides an overview of the history of NPWT and zooms in on the future perspectives of this treatment modality, which could further contribute to the development and refinement of the technique in veterinary medicine. In this review, the term NPWT will be used when referring to the treatment with negative pressure.

\section{HISTORY OF NEGATIVE PRESSURE WOUND THERAPY}

\section{Human medicine}

Negative pressure wound therapy originated in human medicine during the Roman era (around 27 BCE), when people who were thought to have healing powers, used their mouth to apply negative pressure to the wound bed. This type of therapy was called 'human lip service' (Price, 1969; Miller, 2012). During the same era, also heated cupping glasses were used to exert a subatmospheric pressure on wounds to drain fluids. As the cups cooled down, the pressure decreased and negative pressure was attained (Miller, 2012).

In the $18^{\text {th }}$ century, the direct mouth suction was abandoned because it was considered to be repulsive and unpleasant (Price, 1969). The French surgeon, Dominique Anel, was inspired by this ancient technique of wound suction and invented a syringe that mimicked the action of wound suction (Figure 1). It could drain fluids from abscesses, hematomas, deep puncture wounds and even infected sinuses (Price, 1969).

Later, cupping became predominant in NPWT. The 'Glass Leech' was developed in 1821 by Francis Fox, a British physician. This device looked like a leech and presumably drew blood into the suction site (Miller, 2012; Museum of Health Care, 2015) (Figure 2). Thereafter, cups with different shapes and sizes were developed, including associated tubes and bulbs. In this way, exudates from various locations of the body could be extracted (Miller, 2012).

In 1977, Patrick Sames described the use of vacuum by surgeons to drain wounds and the importance to cover these areas. He found a less expensive way to seal these areas by using cling film. It was a new, effective and cheaper way to seal the wound bed for NPWT (Sames, 1977). Around the same time, more articles were published about the effectiveness of vacuum therapy. For example, in 1986, the Russian surgeon, Nail Bagaoutdinov, described a so-called 'vacuum aspiration system' with foam dressing and an irrigation tube for infected wounds. This allowed cleansing and suction of the wound at the same time (Couch and Stojadinovic, 2011; Daar et al., 2016). He tried to get a patent on his technique and device but it was rejected because it looked too much like the Bier Cup, which was a glass cup linked to a manual pump and was used around the 1890's (Otterbourg, 2012). The advantages of the 'vacuum aspiration system' were the removal of secretions with cleansing of the wound and a rapid detoxification (Lockwood et al., 2004). For the first time, with NPWT, it was possible to place mechanical tension on soft tissues and thus provide a growth stimulus for fibroblasts (Nolff et al., 2015c).

As more beneficial effects were discovered, new techniques were proposed. Svedman et al. (1986) described the simultaneous use of suction pressure and continuous or intermittent irrigation of the wound (Svedman et al., 1986). Chariker et al. (1989) proposed a NPWT system with the use of moist medical gauze instead of the customary foam, at a pressure of $-80 \mathrm{mmHg}$. The authors stated that moist gauze avoided the presence of a dead space and minimized eschar formation (Chariker et al., 1989).

In 1993, Fleischmann et al. reported the use of NPWT to treat wounds of fifteen patients with open fractures that were covered by polyvinyl foam, a polyurethane dressing, and a suction device. It resulted in well-cleaned wounds and distinct granulation tissue formation (Fleischmann et al., 1993). Up until this study, the results of NPWT were evaluated by visual aspects, which by nature is subjective. The following years, various methods to measure changes in the wound bed were developed, such as measuring blood 
flow by Laser Doppler (Morykwas et al., 1997), or radioisotope perfusion imaging (Kairinos et al., 2009). These objective methods helped to reveal the effects of NPWT on wound healing.

The commercialization of the modern NPWT system was first done by Kinetic Concepts, Inc., USA (KCI) in 1995, who derived the technique from a large-scale clinical trial of Argenta and Morykwas and called it vacuum-assisted closure (V.A.C.) therapy system (Argenta and Morykwas, 1997). Thereafter, in 1996, Fleischmann developed an intermittent instillation NPWT technique (NPWTi) combining NPWT with wound lavage therapy (Fleischmann et al., 1998). The NPWTi system evolved the following years into an automatic system and in 2001, KCI produced a fully electric device with an automatic electric pump and alarm functions (V.A.C. Instill) to warn when abnormalities occurred (Lehner, 2009). The V.A.C. ultra therapy is the most recently developed system (Kim et al., 2013). With this system, specific settings can be managed, i.e. instil volume, soak time and the time, in which negative pressure is applied between instillation phases (KCI Licensing Inc.).

Benefiting from the pioneering work of $\mathrm{KCI}$, other companies started to develop their own devices, and commercialized these at a lower cost compared to the V.A.C. device (Otterbourg, 2012; Garwood and Steinberg, 2016). Currently, fourteen different manufacturers have commercialized NPWT devices, each providing different types of devices (Glass and Nanchahal, 2012; Dumville et al., 2015).

\section{Veterinary medicine}

During the $20^{\text {th }}$ century and well into in the $21^{\text {st }}$ century, animal studies related to NPWT were mostly performed to support scientific findings in human medicine (Morykwas et al., 1997; Norbury and Kieswetter, 2007; Jacobs et al., 2009; Suh et al., 2016; Tanaka et al., 2016). Morykwas et al. (1997) were the first to set up such animal studies, and used twenty-five pigs to examine the acceleration of wound healing by secondary intention with the V.A.C. device and methodology. Specifically, they examined the effects on blood flow and delivery of nutrients, the development of granulation tissue at continuous and intermittent subatmospheric pressure, and bacterial colonization (Morykwas et al., 1997).

The first reported veterinary case treated with NPWT concerned a tiger of six weeks old with multiple wounds (Lafortune et al., 2007). When conventional wound therapy had failed after dehiscence of a skin flap, NPWT was applied. The authors proposed that the technique could be beneficial in the treatment of complex and chronic wounds in domestic animals, neonatal zoo animals and reptiles (Lafortune et al., 2007).

In the past years, more studies and case reports of various species, such as cats (Guille et al., 2007; Owen et al., 2009; Nolff and Meyer-Lindenberg, 2015a; Nolff and Meyer-Lindenberg, 2015b), dogs (Ben-Amotz et al., 2007; Israel and Hickman, 2011; Buote and Havig, 2012; Cioffi et al., 2012; Spillebeen et al., 2013; Stanley et al., 2013; Pitt and Stanley, 2014; Abma et al., 2015; Coutin et al., 2015; Nolff et al., 2015a; Nolff et al., 2015b; Nolff et al., 2015c; Or et al., 2015; Lippens et al., 2016; Miller et al., 2016; Or et al., 2016), horses (Gemeinhardt and Molnar, 2005), and even birds (Knapp-Hoch and de Matos, 2014), tigers (Lafortune et al., 2007), tortoises (Adkesson et al., 2007), and a rhinoceros (Harrison et al., 2011) were published. Negative pressure wound therapy has been used to accelerate wound closure, stimulate granulation tissue production, immobilize skin grafts, and remove and prevent fluid accumulation (Ben-Amotz et al., 2007; Guille et al., 2007; Stanley et al., 2013). It effectively reduced and closed dead space (Knapp-Hoch and de Matos, 2014), promoted wound contraction, and resolved infection (BenAmotz et al., 2007; Nolff et al., 2015c). It has been used in conjunction with flap surgery (Nolff and Meyer-Lindenberg, 2015b; Or et al., 2015), orthopedic complications (Bertran et al., 2013), necrotizing fasciitis (Abma et al., 2015) and septic peritonitis (Buote and Havig, 2012; Cioffi et al., 2012). Overall, animals have a high tolerance for NPWT and there have been numerous applications in veterinary medicine (Nolff and Meyer-Lindenberg, 2016).

\section{FUTURE PERSPECTIVES IN VETERINARY MEDICINE}

Negative pressure wound therapy appears a promising technique for the treatment of complicated wounds. Negative pressure wound therapy has a history of research and development (Figure 3), but further research is necessary to optimize the technique and its applications in practice, both in human and veterinary medicine. One of the difficulties of comparing the existing literature on NPWT is that outcome measures of NPWT are different, which contribute to reported con-

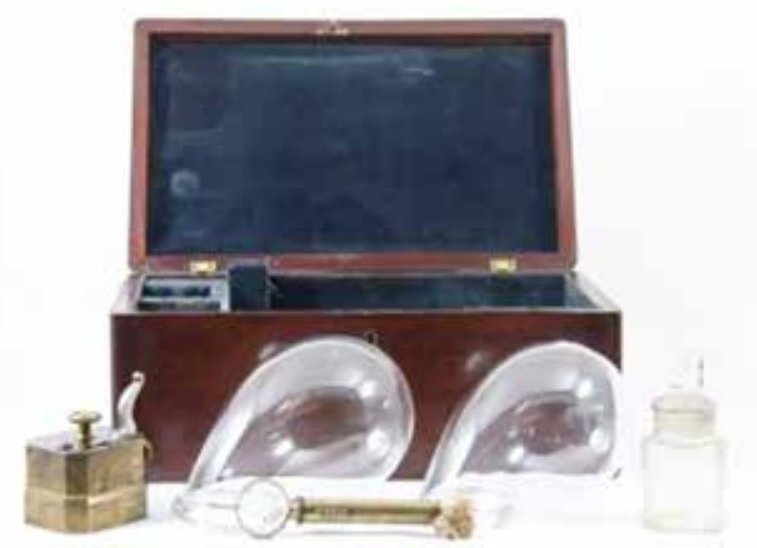

Figure 2. Glass cupping set of Dr. Fox from around 1850 (Anonymous, 2015). 

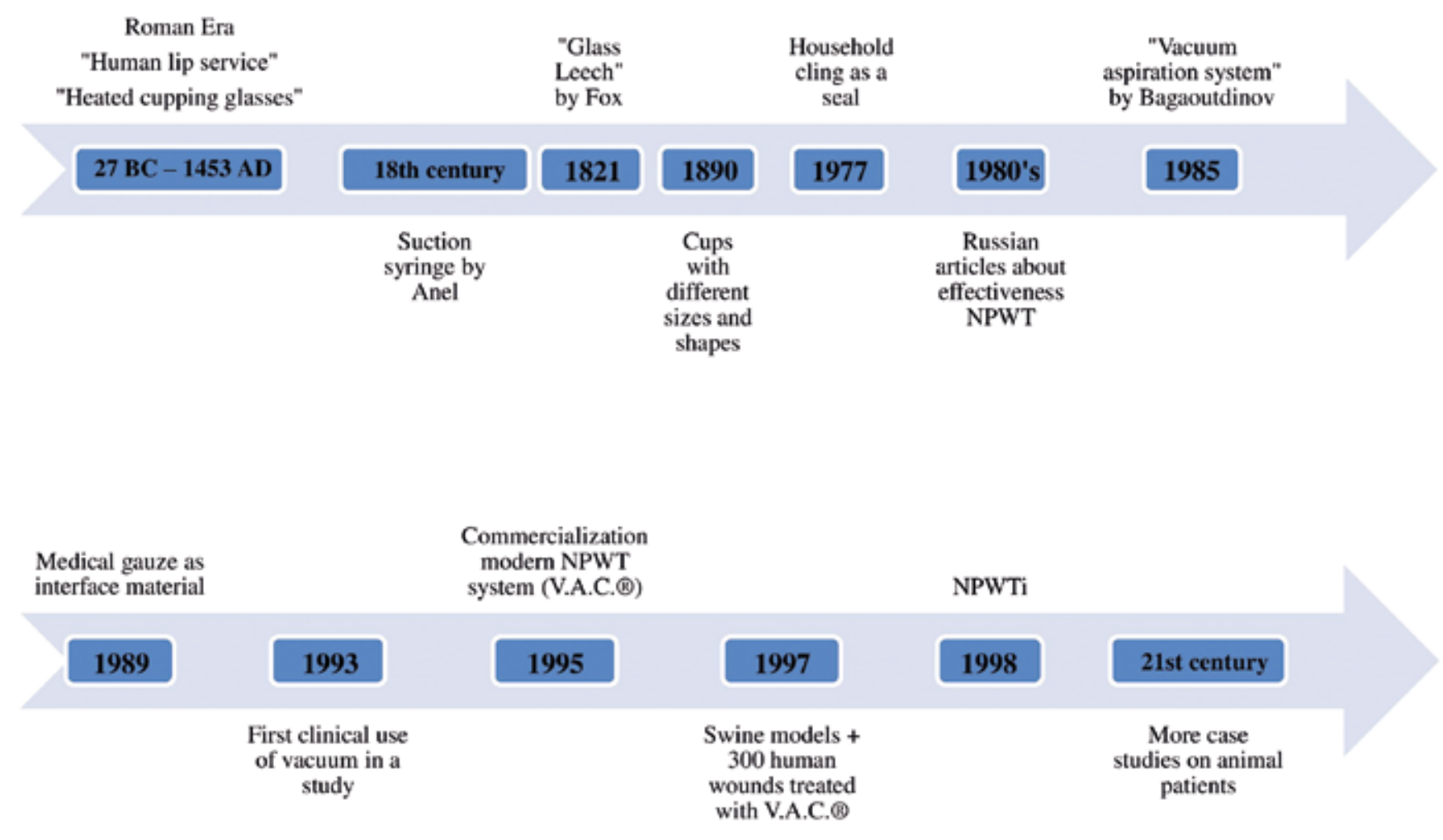

Figure 3. Historical timeline of the use of NPWT.

troversial results. Even when measurement methods could be standardized, it will still remain difficult to objectively compare results, as traumatic wounds are unique. Furthermore, there is a lack of blinded, double-blinded and meta-analysis studies concerning NPWT. Blinding for the treatment protocol is often not possible because wounds and periwound environment show clear evidence of NPWT, predisposing to a bias during wound evaluation (Moues et al., 2007). Furthermore, meta-analysis in the veterinary literature is often not possible due to the relatively limited amount of cases.

Although less important for research purposes but clinically relevant, is the fact that NPWT systems have undergone quite some development. For veterinary use, the V.A.C. simplicity system and the V.A.C. freedom portable devices have recently been introduced (KCI ${ }^{\circledR}$ Animal Health, 2016). Moreover, in an Australian study, the first use of the portable $\mathrm{PICO}^{\mathrm{TM}}$ pump has been described (Miller et al., 2016). This is of great advantage in the veterinary field since incorporation of the vacuum pump into a harness allows patient movement without termination of treatment (Pitt and Stanley, 2014; Coutin et al., 2015; Miller et al., 2016; Nolff and Meyer-Lindenberg, 2016). In this way, NPWT could be used on a home treatment basis, provided that owners are competent enough to manage and closely monitor the system and the health status of their pet. Owners can be trained for home management, reducing the need for a doctor visit to change dressings or when complications are suspected. Prolonged hospitalization and its associated costs can thus be avoided, making pet owners potentially more in favor of performing NPWT (Pitt and Stanley, 2014). It should be emphasized that the consumables used for NPWT are rather costly.

The advent of less bulky NPWT devices might also stimulate the use of NPWT in cats. So far, the use of NPWT in cats has been described in several case reports, a retrospective cohort study and a clinical case series (Guille et al., 2007; Owen et al., 2009; Nolff and Meyer-Lindenberg, 2015a; Nolff and Meyer-Lindenberg, 2015b; Nolff et al., 2016). Currently, there are no experimental studies. More studies in cats would be interesting, for it is believed that NPWT could have the same positive effects in cats as in dogs (Nolff and Meyer-Lindenberg, 2016).

Pressure setting is one of the most studied parameters in various applications of NPWT. Most devices allow the pressure to be set at different values. However the majority of the commercial devices measure the pressure at the pump, while the actual pressure at the wound would be the preferred location for pressure measurement, since this can differ significantly from the pressure at the pump (Nolff and Meyer-Lindenberg, 2016). Pressure recommendations proposed in human medicine have a therapeutic range of -40 to $-150 \mathrm{mmHg}$ (Birke-Sorensen et al., 2011). A pressure of $-125 \mathrm{mmHg}$ has been suggested as the ideal pressure for optimal blood flow and granulation tissue production in animal wounds (Morykwas et al., 2001), although other studies found similar or better effects with other pressure values (Borgquist et al., 2010; Birke-Sorensen et al., 2011). 
In addition to the location of pressure sensing, the transmission of pressure along the wound bed also depends on the interface material used (Or et al., 2016). Along with the development of the NPWT systems, different contact layer materials have been developed, i. e. foams, gauzes, impregnated materials and adhesive or non-adhesive sheets, each having their own recommended indications. Oxidized regenerated cellulose is thought to be a new interface material for NPWT (Glass and Nanchahal, 2012). It adequately drains exudates, it provides inactivation and removal of matrix metalloproteinases, and it absorbs and modulates growth factor release (Glass and Nanchahal, 2012).

Furthermore, it is currently investigated in an interventional study whether a novel contact layer called Bio-Dome (ConvaTec, USA), linked to the Engenex system, is useful in human NPWT patients. Bio-Dome creates space above the wound surface, which prevents ingrowth of granulation tissue into the interface material, and keeps its integrity after initiating the therapy. It seems to have comparable positive effects on wound healing as NPWT systems at the standard pressure of $-125 \mathrm{mmHg}$, and even with less hypobaric pressure (Hoeksema, 2015). Currently, research is still ongoing.

Further treatment improvements may be expected by combining other wound treatment approaches with NPWT. Scaffolds, such as Integra (Integra Lifesciences Corporation, USA), an artificial dermis, have been examined in animal models and in human patients (Machens et al., 2000; Grant et al., 2001; Park et al., 2009). Integra is a dermoconductive product, which stimulates migration of cells into the wound and stimulates the formation of a new dermis (Garwood and Steinberg, 2016). The composition of this material is similar to skin, consisting of a dermal matrix, which helps in the formation of blood vessels and granulation tissue, and a region composed of silicone, which acts as an epidermis. In human patients, Integra has been combined with NPWT (Park et al., 2009). It increases contact with the wound bed, improves graft take and minimizes complications such as the ingrowth of granulation tissue into the contact layer material. Good clinical results have been achieved in human patients after covering exposed bones, tendons and joints (Park et al., 2009).

Furthermore, the possibility of stem cell use in combination with NPWT has been studied. Epidermal, dermal and adipose-derived stem cells are interesting as they have a high level of plasticity (Orgill and Bayer, 2013). The combination of NPWT and mesenchymal stem cells has been studied in rats. The study showed that the vascularization of an acellular dermal matrix is accelerated and improved by combining NPWT and stem cells when compared to the separate use of these techniques (Sahin et al., 2014).

Currently, the effect of NPWT on the bacterial load of wounds remains controversial (Nolff et al., 2015c). Whereas some studies claim reduction of the bacterial burden (Morykwas et al., 1997; Li et al., 2015), many others state otherwise (Weed et al., 2004; Demaria et al., 2011). Instillation NPWT (NPWTi) is a recent therapy, involving the application of topical solutions or bioactive agents such as antiseptics or antibiotics onto the wound bed (Huang et al., 2014). It has proven suitable for contaminated and infected human and animal wounds (Allen et al., 2014; Nolff et al., 2015b; Nolff, 2016). Moreover, it has shown to improve granulation tissue production compared to traditional NPWT, to decrease or prevent bacterial proliferation, and avoid cross-contamination compared to conventional lavage therapy (Lehner et al., 2011; Allen et al., 2014). The current NPWT devices allow for programmed application in order to deliver an antiseptic solution at preset times and volumes. Moreover, continuous application is possible (Gupta et al., 2015; Wolvos, 2015). In comparison to conventional lavage therapy, NPWTi has shown to cause less tissue damage, and therefore less bacterial penetration and clinical infection occurring in the wound (Allen et al., 2014). So far, the application of NPWTi has only been reported twice in veterinary medicine: first as a case report (Nolff et al., 2015b) and recently as a case series (Nolff, 2016). The authors subjectively claimed an improved treatment outcome.

Another potential approach to deal with the bacterial load during NPWT is the concomitant use of interposing dressings that have anti-bacterial properties, such as honey (Rudzka-Nowak et al., 2010; Maguire et al., 2015), or silver (Mullally et al., 2010). Honey may interfere with the proliferation of bacteria, viruses, fungi and protozoa due to its specific characteristics, which are the hydrogen peroxide content (antimicrobial), low $\mathrm{pH}$, hyperosmotic effect, the methylglyoxal content (antimicrobial) and its stimulation of the production of pro-inflammatory cytokines (Rudzka-Nowak et al., 2010; Maguire et al., 2015). Silver has an antimicrobial effect for it can damage the bacterial wall by interfering with DNA and RNA transcription (Mullally et al., 2010). In this way, both honey and silver may lower infection rates, prevent bacteremia and act against resistant microorganisms, such as Staphylococcus aureus and Pseudomonas (Woods et al., 2012; Balsa and Culp, 2015). Considering the beneficial properties of NPWT and an antimicrobial dressing, a combination of these applications has been suggested to be advantageous for wound treatment outcome (Mullally et al., 2010; Rudzka-Nowak et al., 2010). It should be kept in mind that confounding variables including the bacterial species, its virulence, the immune system of the patient and the debridement technique play a critical role in bacterial load and colonization (Moues et al., 2007; Li et al., 2015). For this reason, the construction of studies with a proper control group is questioned (Moues et al., 2007; Glass and Nanchahal, 2012).

The use of NPWT in preventive medicine has 
great potential. Its application on postoperative surgical incisions have been described in humans as well as in animals (Hudson et al., 2015; Nolff and Meyer-Lindenberg, 2016). The beneficial effects include a decrease of edema, seroma and/or hematoma formation, and it may prevent surgical site infections and wound dehiscence (Horch, 2015; Nolff and Meyer-Lindenberg, 2016; Suh et al., 2016). There is only one published case report, which describes preventive incisional NPWT in a Rottweiler (Nolff et al., 2015a). More research with control groups is needed to explore the effects on closed incisions in veterinary medicine.

Lastly, NPWT is not limited to the treatment of wounds. In human patients, open abdomen management with NPWT has lowered morbidity and mortality (Coccolini et al., 2015; Nolff and Meyer-Lindenberg, 2016). Only two case series have been reported in veterinary medicine (Buote and Havig, 2012; Cioffi et al., 2012). In animal patients, open abdomen management is based on establishing drainage, controlling infection and stabilizing the patient with less focus on avoiding fascial retraction (loss of abdominal domain), which is an important issue in human patients (Cioffi et al., 2012; Nolff and Meyer-Lindenberg, 2016). Animal case series describe increased patient comfort, since it is a relatively simple way to manage an open abdomen: dressings may stay in place for several days and movement is enabled with a portable device. Postoperative patient management has also been improved due to the more hygienic management of effusions. Despite these positive findings, there are no studies yet, which compare to a control group (Nolff and Meyer-Lindenberg, 2016).

In conclusion, negative pressure for the treatment of wounds has been applied for centuries. In veterinary medicine however, it has found favor only recently. Positive and promising results have been documented, but more controlled studies are needed to clarify the exact mechanisms and beneficial effects of NPWT in animal patients. At last, establishing better guidelines and recommendations for each indication in human and veterinary medicine will improve the clinical use of this therapy.

\section{REFERENCES}

Abma, E., Kitshoff, A.M., Vandenabeele, S., Bosmans, T., Stock, E., de Rooster, H. (2015). Treatment of necrotizing fasciitis using negative pressure wound therapy in a puppy. Vlaams Diergeneeskundig Tijdschrift 84, 147153.

Adkesson, M.J., Travis, E.K., Weber, M.A., Kirby, J.P., Junge, R.E. (2007). Vacuum-assisted closure for treatment of a deep shell abscess and osteomyelitis in a tortoise. Journal of the American Veterinary Medical Association 231, 1249-1254.

Allen, D., LaBarbera, L.A., Bondre, I.L., Lessing, M.C., Rycerz, A.M., Kilpadi, D.V., Collins, B.A., Perkins, J.,
McNulty, A.K. (2014). Comparison of tissue damage, cleansing and cross-contamination potential during wound cleansing via two methods: lavage and negative pressure wound therapy with instillation. International Wound Journal 11, 198-209.

Argenta, L.C., Morykwas, M.J. (1997). Vacuum-assisted closure: a new method for wound control and treatment: clinical experience. Annals of Plastic Surgery 38, 563577.

Balsa, I.M., Culp, W.T. (2015). Wound care. Veterinary Clinics of North America: Small Animal Practice 45, 1049-1065.

Ben-Amotz, R., Lanz, O.I., Miller, J.M., Filipowicz, D.E., King, M.D. (2007). The use of vacuum-assisted closure therapy for the treatment of distal extremity wounds in 15 dogs. Veterinary Surgery 36, 684-690.

Bertran, J., Farrell, M., Fitzpatrick, N. (2013). Successful wound healing over exposed metal implants using vacuum-assisted wound closure in a dog. Journal of Small Animal Practice 54, 381-385.

Birke-Sorensen, H., Malmsjo, M., Rome, P., Hudson, D., Krug, E., Berg, L., Bruhin, A., Caravaggi, C., Chariker, M., Depoorter, M. (2011). Evidence-based recommendations for negative pressure wound therapy: treatment variables (pressure levels, wound filler and contact layer)-steps towards an international consensus. Journal of Plastic, Reconstructive \& Aesthetic Surgery 64, S1-S16.

Borgquist, O., Ingemansson, R., Malmsjö, M. (2010). Wound edge microvascular blood flow during negative-pressure wound therapy: examining the effects of pressures from-10 to- $175 \mathrm{mmHg}$. Plastic and Reconstructive Surgery 125, 502-509.

Buchanan, P.J., Kung, T.A., Cederna, P.S. (2014). Evidence-based medicine: wound closure. Plastic and Reconstructive Surgery 134, 1391-1404.

Buote, N.J., Havig, M.E. (2012). The use of vacuum-assisted closure in the management of septic peritonitis in six dogs. Journal of the American Animal Hospital Association 48, 164-171.

Chariker, M.E., Jeter, K.F., Tintle, T.E., Bottsford, J. (1989). Effective management of incisional and cutaneous fistulae with closed suction wound drainage. Contemporary Surgery 34, 59-63.

Cioffi, K.M., Schmiedt, C.W., Cornell, K.K., Radlinsky, M.G. (2012). Retrospective evaluation of vacuum-assisted peritoneal drainage for the treatment of septic peritonitis in dogs and cats: 8 cases (2003-2010). Journal of Veterinary Emergency and Critical Care 22, 601-609.

Coccolini, F., Biffl, W., Catena, F., Ceresoli, M., Chiara, O., Cimbanassi, S., Fattori, L., Leppaniemi, A., Manfredi, R., Montori, G. (2015). The open abdomen, indications, management and definitive closure. World Journal of Emergency Surgery 10, 32-42.

Couch, K.S., Stojadinovic, A. (2011). Negative-pressure wound therapy in the military: lessons learned. Plastic and Reconstructive Surgery 127, 117S-130S.

Coutin, J.V., Lanz, O.I., Magnin-Bissel, G.C., Ehrich, M.F., Miller, E.I., Werre, S.R., Riegel, T.O. (2015). Cefazolin concentration in surgically created wounds treated with negative pressure wound therapy compared to surgically created wounds treated with nonadherent wound dressings. Veterinary Surgery 44, 9-16.

Daar, D.A., Wirth, G.A., Evans, G.R., Carmean, M., Gordon, I.L. (2016). The Bagautdinov dressing method: negative pressure wound therapy in a patient with an allergy 
to acrylate adhesive. International Wound Journal 14, 198-202.

Demaria, M., Stanley, B.J., Hauptman, J.G., Steficek, B.A., Fritz, M.C., Ryan, J.M., Lam, N.A., Moore, T.W., Hadley, H.S. (2011). Effects of negative pressure wound therapy on healing of open wounds in dogs. Veterinary Surgery 40, 658-669.

Dumville, J.C., Owens, G.L., Crosbie, E.J., Peinemann, F., Liu, Z. (2015). Negative pressure wound therapy for treating surgical wounds healing by secondary intention. The Cochrane Library 6, 2-14.

Fleischmann, W., Russ, M., Westhauser, A., Stampehl, M. (1998). Vacuum-sealing-technique used as drug release system for topical treatment of wound infections. Der Unfallchirurg 101, 649-654.

Fleischmann, W., Strecker, W., Bombelli, M., Kinzl, L. (1993). Vacuum sealing as treatment of soft tissue damage in open fractures. Der Unfallchirurg 96, 488-492.

Museum of Health Care Fox's glass leech cupping set. Retrieved August 2015, from http://artefact.museumofhealthcare.ca/ $? \mathrm{p}=173$

Garwood, C.S., Steinberg, J.S. (2016). What's new in wound treatment: a critical appraisal. Diabetes/metabolism Research and Reviews 32, 268-274.

Gemeinhardt, K., Molnar, J. (2005). Vacuum-assisted closure for management of a traumatic neck wound in a horse. Equine Veterinary Education 17, 27-33.

Glass, G.E., Nanchahal, J. (2012). The methodology of negative pressure wound therapy: Separating fact from fiction. Journal of Plastic, Reconstructive \& Aesthetic Surgery 65, 989-1001.

Grant, I., Green, C., Martin, R. (2001). Strategies to improve the take of commercially available collagen/glycosaminoglycan wound repair material investigated in an animal model. Burns 27, 699-707.

Guille, A.E., Tseng, L.W., Orsher, R.J. (2007). Use of vacuum-assisted closure for management of a large skin wound in a cat. Journal of the American Veterinary Medical Association 230, 1669-1673.

Gupta, S., Gabriel, A., Lantis, J., Téot, L. (2015). Clinical recommendations and practical guide for negative pressure wound therapy with instillation. International Wound Journal 13, 159-174.

Harrison, T.M., Stanley, B.J., Sikarskie, J.G., Bohart, G., Ames, N.K., Tomlian, J., Marquardt, M., Marcum, A., Kiupel, M., Sledge, D. (2011). Surgical amputation of a digit and vacuum-assisted-closure (VAC) management in a case of osteomyelitis and wound care in an Eastern black rhinoceros (Diceros bicornis michaeli). Journal of Zoo and Wildlife Medicine 42, 317-321.

Hoeksema, H., Verbelen, J. (2015). Negative pressure wound therapy with the Engenex ${ }^{\mathrm{TM}_{-}}$-pump and BioDome $^{\text {TM }}$ dressing, an evaluation. U.S. National Institutes of Health. April 8, 2010, from https://clinicaltrials.gov/ ct2/show/study/NCT01107821

Horch, R.E. (2015). Incisional negative pressure wound therapy for high-risk wounds. Journal of Wound Care 24, 21-28.

Howe, L.M. (2015). Current concepts in negative pressure wound therapy. Veterinary Clinics of North America: Small Animal Practice 45, 565-584.

Huang, C., Leavitt, T., Bayer, L.R., Orgill, D.P. (2014). Effect of negative pressure wound therapy on wound healing. Current Problems in Surgery 51, 301-331.

Hudson, D.A., Adams, K.G., Van Huyssteen, A., Martin,
R., Huddleston, E.M. (2015). Simplified negative pressure wound therapy: clinical evaluation of an ultraportable, no-canister system. International Wound Journal 12, 195-201.

Israel, S., Hickman, S. (2011). Case brief: successful treatment of canine snake bite wound on the submandibular area with V.A.C. ${ }^{\circledR}$ Therapy (San Antonio, Texas, KCI Licensing, Inc.).

Jacobs, S., Simhaee, D.A., Marsano, A., Fomovsky, G.M., Niedt, G., Wu, J.K. (2009). Efficacy and mechanisms of vacuum-assisted closure (VAC) therapy in promoting wound healing: a rodent model. Journal of Plastic, Reconstructive \& Aesthetic Surgery 62, 1331-1338.

Jordana-Garcia, M., Pint, E., Martens, A. (2011). The use of vacuum-assisted wound closure to enhance skin graft acceptance in a horse. Vlaams Diergeneeskundig Tijdschrift 80, 343-350.

Kairinos, N., Voogd, A.M., Botha, P.H., Kotze, T., Kahn, D., Hudson, D.A., Solomons, M. (2009). Negative-pressure wound therapy II: negative-pressure wound therapy and increased perfusion. Just an illusion? Plastic and Reconstructive Surgery 123, 601-612.

Kim, P.J., Attinger, C.E., Steinberg, J.S., Evans, K.K., Lehner, B., Willy, C., Lavery, L., Wolvos, T., Orgill, D., Ennis, W. (2013). Negative-pressure wound therapy with instillation: international consensus guidelines. Plastic and Reconstructive Surgery 132, 1569-1579.

Knapp-Hoch, H., de Matos, R. (2014). Clinical technique: negative pressure wound therapy - general principles and sse in avian species. Journal of Exotic Pet Medicine 23, 56-66.

Lafortune, M., Fleming, G.J., Wheeler, J.L., Göbel, T., Mozingo, D.W. (2007). Wound management in a juvenile tiger (Panthera tigris) with vacuum-assisted closure (VAC therapy). Journal of Zoo and Wildlife Medicine 38, 341-344.

Lehner, B. (2009). VAC Instill (R) therapy-indications and technical applications First VAC Instill (R) symposium in Germany November 21 (st) 2008 in Heidelberg. Urban \& Vogel, Munich, Germany, p. 4.

Lehner, B., Fleischmann, W., Becker, R., Jukema, G.N. (2011). First experiences with negative pressure wound therapy and instillation in the treatment of infected orthopaedic implants: a clinical observational study. International Orthopaedics 35, 1415-1420.

Li, T., Wang, G., Yin, P., Li, Z., Zhang, L., Liu, J., Li, M., Zhang, L., Han, L., Tang, P. (2015). Effect of negative pressure on growth, secretion and biofilm formation of Staphylococcus aureus. Antonie van Leeuwenhoek 108, 907-917.

Lippens, S., Furcas, A., Or, M., Van Goethem, B., Polis, I., de Rooster, H. (2016). Behandeling van een chronische huidwonde bij een hond via negatieve druktherapie. Vlaams Diergeneeskundig Tijdschrift 85, 206-214.

Lockwood, J.S., Petrosenko, R., Risk Jr, J.R. (2004). Vacuum therapy and cleansing dressing for wounds. Google Patents. Patent, U.S. US006685681B2.

Machens, H.-G., Berger, A., Mailaender, P. (2000). Bioartificial skin. Cells Tissues Organs 167, 88-94.

Maguire, P., Azagrar, J.M., Carb, A., Lesser, A. (2015). The successful use of negative-pressure wound therapy in two cases of canine necrotizing fasciitis. Journal of the American Animal Hospital Association 51, 43-48.

Miller, A., Cashmore, R., Marchevsky, A., Havlicek, M., Brown, P., Fearnside, S. (2016). Negative pressure 
wound therapy using a portable single-use device for free skin grafts on the distal extremity in seven dogs. Australian Veterinary Journal 94, 309-316.

Miller, C. (2012). The history of negative pressure wound therapy (NPWT): from "lip service" to the modern vacuum system. Journal of the American College of Clinical Wound Specialists 4, 61-62.

Morykwas, M.J., Argenta, L.C., Shelton-Brown, E.I., McGuirt, W. (1997). Vacuum-assisted closure: a new method for wound control and treatment: animal studies and basic foundation. Annals of Plastic Surgery 38, 553562.

Morykwas, M.J., Faler, B.J., Pearce, D.J., Argenta, L.C. (2001). Effects of varying levels of subatmospheric pressure on the rate of granulation tissue formation in experimental wounds in swine. Annals of Plastic Surgery 47, 547-551.

Moues, C., Van Den Bemd, G., Heule, F., Hovius, S. (2007). Comparing conventional gauze therapy to vacuum-assisted closure wound therapy: a prospective randomised trial. Journal of Plastic, Reconstructive \& Aesthetic Surgery 60, 672-681.

Mullally, C., Carey, K., Seshadri, R. (2010). Use of a nanocrystalline silver dressing and vacuum-assisted closure in a severely burned dog. Journal of Veterinary Emergency and Critical Care 20, 537-537.

Nolff, M., Flatz, K., Meyer-Lindenberg, A. (2015a). Preventive incisional negative pressure wound therapy (Prevena) for an at-risk-surgical closure in a female Rottweiler. Schweizer Archiv fur Tierheilkunde 157, 105-109.

Nolff, M., Layer, A., Meyer-Lindenberg, A. (2015b). Negative pressure wound therapy with instillation for body wall reconstruction using an artificial mesh in a Dachshund. Australian Veterinary Journal 93, 367-372.

Nolff, M., Meyer-Lindenberg, A. (2015a). Necrotising fasciitis in a domestic shorthair cat-negative pressure wound therapy assisted debridement and reconstruction. Journal of Small Animal Practice 56, 281-284.

Nolff, M., Meyer-Lindenberg, A. (2016). Negative pressure wound therapy in small animal medicine. Tierärztliche Praxis Kleintiere 44, 26-37.

Nolff, M.C. (2016). Comparison of antibacterial efficiacy of standard negative pressure wound therapy (NPWT) and negative pressure wound therapy with instillation (NPWTi) in the dog. In 25th Annual Scientific Meeting (Centro Cultural de Belém, Lisbon, Portugal).

Nolff, M.C., Fehr, M., Bolling, A., Dening, R., Kramer, S., Reese, S., Meyer-Lindenberg, A. (2015c). Negative pressure wound therapy, silver coated foam dressing and conventional bandages in open wound treatment in dogs. A retrospective comparison of 50 paired cases. Veterinary and Comparative Orthopaedics and Traumatology 28, 30-38.

Nolff, M.C., Fehr, M., Reese, S., Meyer-Lindenberg, A.E. (2016). Retrospective comparison of negative-pressure wound therapy and silver-coated foam dressings in openwound treatment in cats. Journal of Feline Medicine and Surgery, DOI: 10.1177/1098612X16645141.

Nolff, M.C. and Meyer-Lindenberg, A. (2015b). Negative pressure wound therapy augmented full-thickness free skin grafting in the cat: outcome in 10 grafts transferred to six cats. Journal of Feline Medicine and Surgery17, 1041-1048.

Norbury, K., Kieswetter, K. (2007). Vacuum-assisted closure therapy attenuates the inflammatory response in a porcine acute wound healing model. Wounds: A Compendium of Clinical Research and Practice 19, 97-106.

Or, M., Van Goethem, B., Kitshoff, A.M., Koenraadt, A., Schwarzkopf, I., Bosmans, T., De Rooster, H. (2016). Negative pressure wound therapy using polyvinyl alcohol foam to support full-thickness mesh skin grafts in dogs. Veterinary Surgery 46, 389-395.

Or, M., Van Goethem, B., Polis, I., Spillebeen, A., Vandekerckhove, P., Saunders, J. and de Rooster, H. (2015). Pedicle digital pad transfer and negative pressure wound therapy for reconstruction of the weight-bearing surface after complete digital loss in a dog. Veterinary Comparative Orthopaedics and Traumatology 28, 140-144.

Orgill, D.P., Bayer, L.R. (2013). Negative pressure wound therapy: past, present and future. International Wound Journal 10, 15-19.

Otterbourg, K. (2012). The bloody patent battle over a healing machine. Fortune. http://fortune.com/2012/10/30/ the-bloody-patent-battle-over-a-healing-machine/

Owen, L., Hotston-Moore, A., Holt, P. (2009). Vacuum-assisted wound closure following urine-induced skin and thigh muscle necrosis in a cat. Veterinary Comparitive Orthopaedics and Traumatology 22, 417-421.

Park, C.A., Defranzo, A.J., Marks, M.W., Molnar, J.A. (2009). Outpatient reconstruction using integra and subatmospheric pressure. Annals of Plastic Surgery 62, 164169.

Pitt, K.A., Stanley, B.J. (2014). Negative pressure wound therapy: experience in 45 dogs. Veterinary Surgery 43, 380-387.

Price, J. (1969). Dominique Anel and the small lachrymal syringe. Medical History 13, 340-354.

Rudzka-Nowak, A., Luczywek, P., Gajos, M.J., Piechota, M. (2010). Application of Manuka honey and GENADYNE A4 negative pressure wound therapy system in a 55-year-old woman with extensive phlegmonous and necrotic lesions in the abdominal integuments and lumbar region after traumatic rupture of the colon. Medical Science Monitor 16, CS138-CS142.

Sahin, I., Ozturk, S., Deveci, M., Ural, A.U., Onguru, O., Isik, S. (2014). Experimental assessment of the neo-vascularisation of acellular dermal matrix in the wound bed pretreated with mesenchymal stem cell under subatmospheric pressure. Journal of Plastic, Reconstructive \& Aesthetic Surgery 67, 107-114.

Sames, C.P. (1977). Sealing of wounds with vacuum drainage. British Medical Journal 2, 1223.

Spillebeen, A., Or, M., Van Goethem, B., De Rooster, H. (2013). Negatieve druktherapie ter bevordering van de wondheling bij gezelschapsdieren. Vlaams Diergeneeskundig Tijdschrift 82, 191-200.

Stanley, B.J., Pitt, K.A., Weder, C.D., Fritz, M.C., Hauptman, J.G., Steficek, B.A. (2013). Effects of negative pressure wound therapy on healing of free full-thickness skin grafts in dogs. Veterinary Surgery 42, 511-522.

Suh, H., Lee, A.-Y., Park, E.J., Hong, J.P. (2016). Negative pressure wound therapy on closed surgical wounds with dead space: animal study using a swine model. Annals of Plastic Surgery 76, 717-722.

Svedman, P., Sandén, G., Arnljots, B., Banck, G. (1986). A dressing system providing fluid supply and suction drainage used for continuous or intermittent irrigation. Annals of Plastic Surgery 17, 125-133.

Tanaka, T., Panthee, N., Itoda, Y., Yamauchi, N., Fukayama, M., Ono, M. (2016). Negative pressure wound 
therapy induces early wound healing by increased and accelerated expression of vascular endothelial growth factor receptors. European Journal of Plastic Surgery 39, 247-256.

KCI Licensing Inc., V.A.C. Ulta ${ }^{\mathrm{TM}}$ Products. Retrieved August 2015, from http://vaculta.com/products/

KCI ${ }^{\circledR}$ Animal Health V.A.C.® Therapy Products. Retrieved March 2016, from http://kcianimalhealth.com/ products/

Weed, T., Ratliff, C., Drake, D.B. (2004). Quantifying bacterial bioburden during negative pressure wound therapy: does the wound VAC enhance bacterial clearance? Annals of Plastic Surgery 52, 276-279.

Wolvos, T. (2015). The evolution of negative pressure wound therapy negative pressure wound therapy with instillation. Journal of Wound Care 24.

Woods, S., de Castro Marques, A.I., Renwick, M.G., Argyle, S.A., Yool, D.A. (2012). Nanocrystalline silver dressing and subatmospheric pressure therapy following neoadjuvant radiation therapy and surgical excision of a feline injection site sarcoma. Journal of Feline Medicine and Surgery 14, 214-218.

\section{VAN ALLE TIJDEN: SLECHTE BETALERS}

Pieter Milliau, een van de eerste Vlaamse dierenartsen gediplomeerd aan de nieuwe veeartsenijschool van Alfort (Parijs), kreeg in 1790 al te maken met slechte betalers. De 'peerdemeester' spande een zaak in voor de rechtbank die de beschuldigde, Joannes Colle voerman en buurman van Milliau in de Gentse Dampoortststraat (Jooremaykensmeersch) veroordeelde tot het betalen van de verschuldigde 4 pond - 3 schellingen - 6 groten ' (ongeveer 20 bouwvakkersdaglonen uit die tijd) voor het 'cureren van (de) 'peerden ende leveringen van medecynen ende salven'. De heren rechters namen (toen al) hun tijd. De uitspraak volgde precies twee jaar na de aanklacht. Bron: Bibliotheek UGent, Ephemera, chevaux 